\title{
Isolation, characterization and chromosomal localization of the human GADD153 gene
}

(DNA damage; methyl methanesulfonate; 12-O-tetradecanoylphorbol-13-acetate; gene regulation; transcriptional regulation)

Jong Sung Park ${ }^{\text {, Jennifer D. Luethy }}{ }^{\text {, }}$, Mary G. Wang ${ }^{c}$, Joseph Fargnoli ${ }^{\text {, }}$, Albert J. Fornace Jr. ${ }^{\text {, }}$ O. Wesley McBride ${ }^{c}$ and Nikki J. Holbrook ${ }^{a}$

"Laboratory of Molecular Genetics, Gerontology Research Center, National Institute on Aging. Baltimore, MD 21224 (USA): " Laboratory of Molecular Pharmacology' and "Laboratory of Biochemistry. National Cancer Institute, Bethesda, MD 20892 (USA) Tel. (410)558-8162

Received by J. Piatigorsky: 9 December 1991; Revised/Accepted: 9 January/10 January 1992; Received at publishers: 27 February 1992

\section{SUMMARY}

We report the isolation and characterization of the growth arrest and DNA-damage-inducible gene, GADD153, from human cells and show that it is localized in the region 12q13.1-q13.2 on chromosome 12. Comparison of the human gene with the previously described hamster gene revealed a high level of conservation in both the structural and regulatory regions of the genes. Each is composed of four exons with intron/exon junctions maintained at the identical positions. The human Gadd 153 protein shares $91 \%$ identity with the hamster protein in amino acid sequence, and $78 \%$ identity in nucleotide sequence. A 900-bp fragment of $5^{\prime}$ flanking sequence from the human gene, when linked to the bacterial cat reporter gene, was found to exhibit promoter activity in HeLa cells which could be further activated by treatment with the DNA alkylating agent, methyl methanesulfonate. Sequence analysis indicated that the human promoter region is relatively $\mathrm{G}+\mathrm{C}$-rich and contains putative binding sites for multiple transcription factors, including recognition sites for TATA- and CAAT-binding proteins, six Spl-binding sites, an activator protein-1 binding site, an E-26-specific sequence-binding protein1 DNA-binding site, and four interleukin-6 response elements. Many of these sites are also present in an identical position in the hamster gene suggesting they may play an important role in regulating GADD153 expression.

\section{INTRODUCTION}

The molecular response to DNA damage has been extensively studied in prokaryotes (Walker, 1985). By comparison, little is known about the response to DNA

Correspondence to: Dr. N.J. Holbrook, Laboratory of Molecular Genetics, Gerontology Research Center, National Institute on Aging, 4940 Eastern Ave., Baltimore, MD 21224 (USA) Tel. (410)558-8162; Fax (410)558-8157.

Abbreviations: aa, amino acid(s); AP-1, activator protein-1; bp, base pair(s); CAT, chloramphenicol acetyltransferase; cat, gene encoding CAT; $\mathrm{CHO}$, Chinese hamster ovary; EGR1, early growth response gene encoding protein-1: ETS-1 and ETS-2, virus E-twenty-six-specific sequence- damage in eukaryotes. While numerous genes have been shown to be activated by genotoxic agents in mammalian cells, few of these have been examined in detail (reviewed in Holbrook and Fornace, 1991).

Recently, we reported the isolation of a novel DNA-

binding protein-1 and -2 , respectively; FITC, fluorescein isothiocyanale; $G A D D 153$, growth arrest and DNA-damage-inducible human gene; Gadd153, protein product of GADD153; IL-6, interleukin-6; kb, kilobase(s) or $1000 \mathrm{bp}$; MMS, methyl methanesulfonate; NRF-2, nuclear respiratory factor-2; nt, nucleotide(s); PCR, polymerase chain reaction; PEA3, polyomavirus enhancer A-binding protein 3; Spl, sequencespecific DNA-binding protein 1; SSC, $0.15 \mathrm{M} \mathrm{NaCl} / 0.015 \mathrm{M} \mathrm{Na}_{3}$.citrate pH 7.6; TPA, 12-O-tetradecanoylphorbol-13-acetate; tsp, transcription start point(s); UV, ultraviolet light. 
Hu agagacttangtctaaggeactgagrcgtateATGTTAAAGATGAGCGGGTGGCAGCGACAGAGCCAAAATCAGAGCTGGAACCTGAGGAGAGAGTGTTCA 100

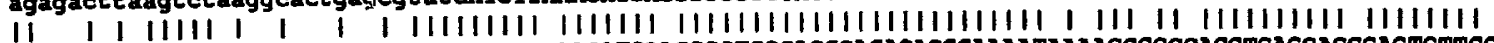

Ba AGTAGCCTGAGTCTCACACTTCGGTCATATCATGTIGAAGATGAACGgGTGCAGCGACAGAGCCAAAATAAAAGCCGGGACCTGAGGAGCGAGTGTTCC

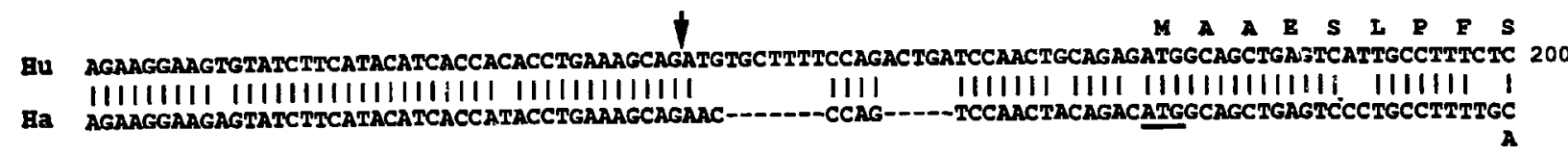

D.

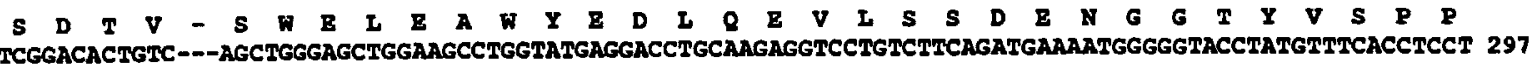

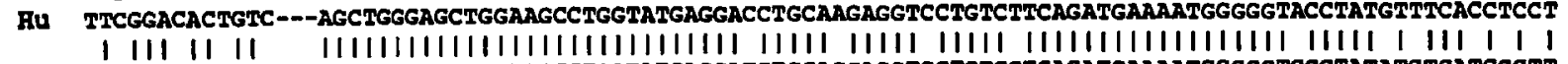

Ha CTTGGAGACGGTGTCAGCTGGGAGCTGGAAGCCTGGTATGAGGATCTGCAGGAGGTGCTGTCCTCAGATGAAAATGGGGTCCCTATATCTCATCCCTT

$\begin{array}{lllll}L & B & S & I & S\end{array}$

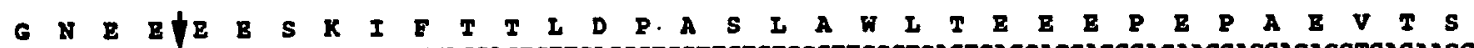

Hu GGAAATGAAGAGGAAGATCAAAAATCTTCACCACTCTTGACCCTGCTTCTCTGGCTTGGCTGACTGAGGAGGAGCCAGAACCAGCAGAGGTCACAAGCA 397

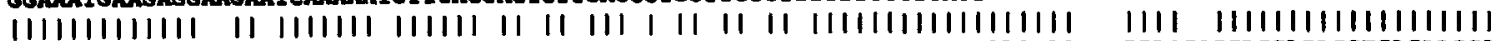

Ha GGAAATGAAGAGgGgagTCAAAAACCTTCACTACCCTAGACTCCGCATCCCTAGCTTGGCTGACTGAGGAG---CCAGgGCCAGCAGAGGTCACAAGCA

G T S

$-\quad \mathbf{G}$

$\begin{array}{llllllllllllllllllllllllllllllllll}T & S & Q & S & P & B & S & P & D & S & S & Q & S & S & L & A & Q & E & E & E & E & E & D & Q & G & R & T & R & K & R & X & Q & S & G\end{array}$

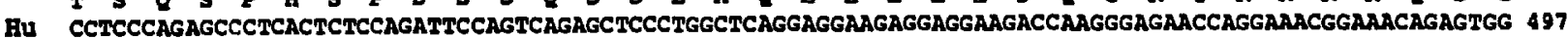

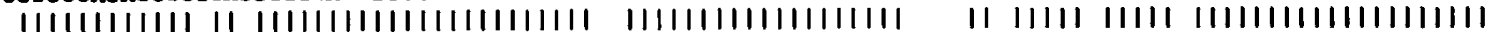

Ha GCTCCCAGAGCCCCCAATCTCCAGATTCCAGTCAGAGCTCTATGGCTCAGGAGGAAGAGGAA---GATCAAGGAAGAACTAGGAAACGGAAACAGAGTGG

$S \quad Q \quad M \quad-$

$\begin{array}{lllllllllllllllllllllllllllllllllll} & H & S & P & A & R & A & G & K & Q & R & M & K & E & K & E & Q & E & N & B & R & K & V & A & Q & L & A & B & E & N & B & R & L & K\end{array}$

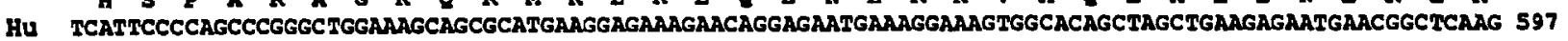

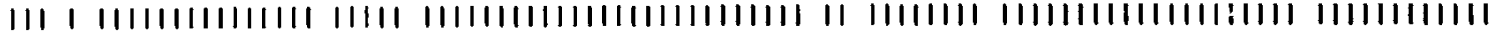

Ha TCAGTGCCCAGCCCGGCTGGGAGGCAACGCATGAAGGAGAAAGAACAGGAGAACGAGAGGAAGTAGCACAGCTAGCTGAAGAGACGAACGGCTCAAG

Q c

$\begin{array}{lllllllllllllllllllllllllll}Q & E & I & E & R & L & T & R & E & V & E & A & T & R & R & A & L & I & D & R & M & V & \text { N } & L & \text { L } & 0 & A\end{array}$

Hu CAGgAAATCGAGCGCCTGACCAGGGAAGTAGAGGCGACTCGCCGAGCTCTGATTGACCGAATGGTGAATCTGCACCAAGCATGAACAATTGGGAGCATCA 697

IIIIIIIIIIIIIIIIIIIIIIIII IIIIIIII IIIIIII IIIIIIIIIIIIII IIIII IIIIIIII IIII |IIIIIIIIIIII IIIII

Ha CAGGAAATCGAGCGCTGACCAGGGAgGTAGAGgCCACTEGCCGgGCTCTGATTGACCGCATGgTAAATCTGCAACAAgTATGACAMTTGGGACCATCA

Hu GTCCCCCACTTGGGCCACACTACCCACCTTTCCCAGAAGTGGCTACTGACTACCCTCTCACTAGTGCCAATGATGTGACCCTCAATCCCACATACGCAGG 797

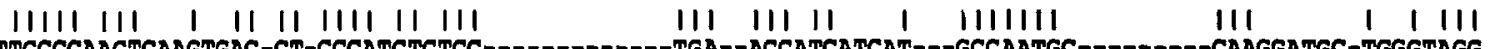

Ha TTCCCCAACTCAAGTGAC-CT-CCCATCTCTCC-----------TGA--ACCATCATCAT---GCCAATGC--------CAAGGATGC-TGGGTAGG

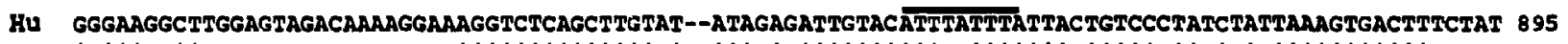
I III II IIIIIIIIIIIIII I III I IIIIIIIIII IIIIIII IIIII II I I 11111111111

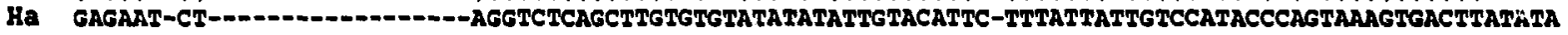

Fig. 1. Comparison of transcribed sequences of the human ( $\mathrm{Hu}$ ) and hamster $(\mathrm{Ha})$ GADD153 genes. The first 31-bp of the human sequence (lower case) were not present in the cDNA but were derived from the genomic sequence. Arrows indicate the exon/intron junctions in the mature GADDI53 mRNA transeript. The au sequence for the human Gadd 153 protein is shown above the corresponding $\mathrm{nt}$ sequences (aa aligned with second $\mathrm{nt}$ of each codon). Only aa which differ from the human protein are indicated for the hamster protein. Sone nt of the hamster $\mathrm{cDNA}$ shown here differ from those of the cDNA isolate we previously reported (Fornace el al., 1989) and reflect true differences between the sequences of the isolates obtained from different libraries. The sequence shown here also agrees with that determined from a genomic library (Luethy et al., 1990) and is presumed to be representative of the hamster gene. The start and stop codons are underlined. Two overlapping ATTTA pentamers present in the $3^{\prime}$-untranslated region of the gene are overlined.

damage-inducible gene, GADD153, from hamster cells (Luethy et al., 1990), which is one of five different genes found to be coordinately induced by treatments which either result in growth arrest or DNA damage (Fornace et al., 1989). It is ubiquitously expressed in different cell types and highly conserved among mammalian species. Analysis of the $5^{\prime}$ flanking sequences of the hamster GADDI53 gene has revealed a complex $\mathrm{G}+\mathrm{C}$-rich promoter region with potential binding sites for multiple transcription factors (Luethy et al., 1990). An 800-bp segment encompassing this region has been shown to exhibit promoter activity that is strongly enhanced by treatment with a variety of DNA damaging agents (Luethy and Holbrook, 1992). In efforts to define which sequences play a key role in the expression of $G A D D 153$, we have cloned the human gene. Our rationale was based on existing knowledge from other genes that sequences important for transcriptional regulation are highly conserved across species. We report here the structure of the human GADD153 gene, its chromosomal localization, the nucleotide sequence of its mRNA and of 900 bp of the promoter region. Comparison of the human and hamster GADD153 genes reveals high conservation throughout both structural and regulatory regions. 
$\mathbf{A}$

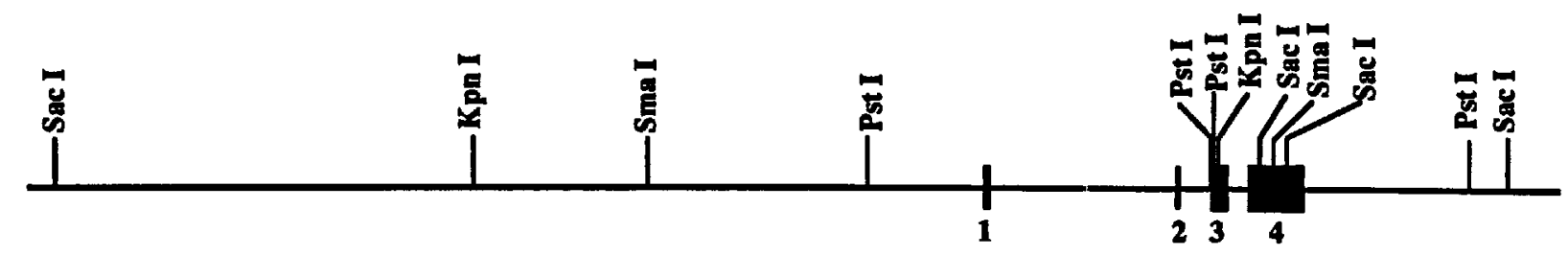

$\mathbf{B}$

$\mathbf{K P}$

b4-1

C
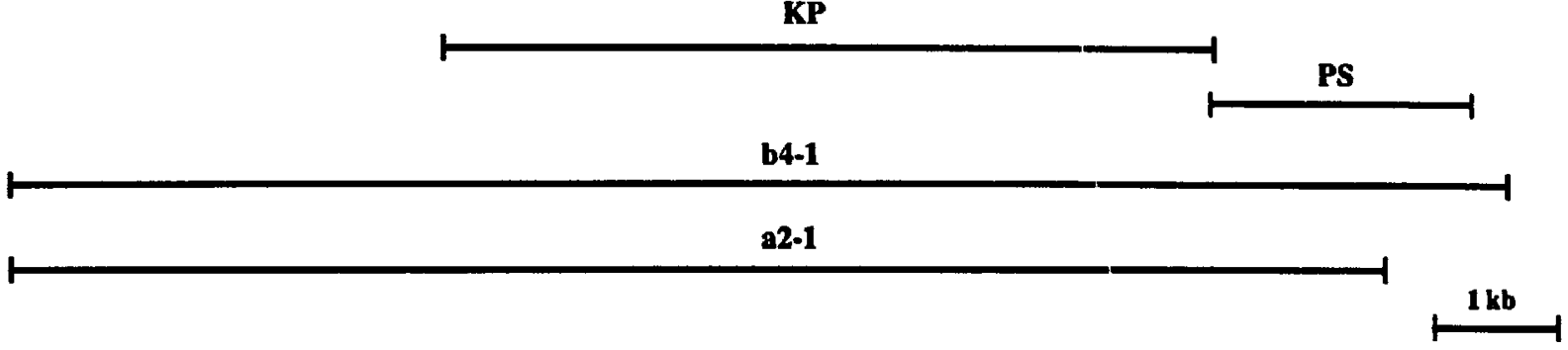

Fig. 2. Structure of the human GADDI53 gene. (A) Restriction map of the human GADDI53 gene and flanking sequences. The four exons are designated as blackened boxes and are numbered 1-4. (B) Genomic sequences (KP and PS) subcloned into the pBlueseriptll SK(+) vector using the restriction sites shown in A. (C) Two genomic clones (b4-I and a2-1) isolated from a human fibroblast genomic library corstructed in bacteriophage $\lambda$ Fix.

\section{RESULTS AND DISCUSSION}

(a) Isolation of a human GADD153 cDNA and comparison of transcribed sequences of the human and the hamster GADD153 genes

Using the previously described hamster GADD153 cDNA as a probe, a cDNA corresponding to human GADD153 was isolated from the Okayama-Berg GM637 human fibroblast library (Chin et al., 1984). Fig. 1 shows a comparison of the sequences of the transcribed mRNAs from the human and the hamster GADD153 genes. The first $31 \mathrm{bp}$ of the human sequence (shown in lower-case letters) were not present in our cDNA isolate, thus sequences were derived from the genomic clones (discussed below). The transcripts share a high degree of identity at the nt level
$(78 \%)$ and the aa level $(91 \%)$. Neither gene has a typical or recognizable polyadenylation site (AAUAAA).

An interesting feature of the human GADD153 transcript is the presence of two overlapping AUUUA pentamers in the $3^{\prime}$-untranslated portion of the mRNA. These sequences have been shown to be associated with instability of a number of mRNAs which are transiently expressed and have short half lives, such as oncogenes, cytokines, and transcriptional factors (Brawerman, 1989). Consistent with the presence of these sequences, GADD153 has a short half life in proliferating cells (S.G. Carlson and N.J.H., unpublished results). Also overlapping this region is the 8-bp sequence 5'-TTATTTAT, which is particularly prevalent among mRNAs encoding proteins related to the inflammatory response (Caput et al., 1986).

\section{TABLE I}

Comparison of exon/intron junctions of the GADD153 gene in human fibroblast and CHO cells

\begin{tabular}{|c|c|c|c|c|c|}
\hline & \multicolumn{2}{|c|}{ Exon" } & \multicolumn{2}{|c|}{ Sequence at exon/intron junction ${ }^{b}$} & \multirow{2}{*}{$\begin{array}{l}\text { Intron } \\
\text { size }\end{array}$} \\
\hline & No. & size (bp) & 5 '-splice donor & 3 'splice acceptor & \\
\hline $\begin{array}{l}\text { Human } \\
\text { CHO }\end{array}$ & $\begin{array}{l}1 \\
1\end{array}$ & $\begin{array}{l}94 \\
94\end{array}$ & $\begin{array}{l}\text { AGAGAG } \\
\text { AGCGAG }^{94} / \text { gcgagtactg } \\
\text { gcgagtaceg }\end{array}$ & $\begin{array}{l}\text { ttgcccacag/ } / 95 \text { TGTTCA } \\
\text { ttcaccacag/ } / 95 \text { TGTTCC }\end{array}$ & $\begin{array}{l}\text { approx. } 1.5 \mathrm{~kb} \\
\text { approx. } 2.4 \mathrm{~kb}\end{array}$ \\
\hline $\begin{array}{l}\text { Human } \\
\text { CHO }\end{array}$ & $\begin{array}{l}2 \\
2\end{array}$ & $\begin{array}{l}48 \\
48\end{array}$ & $\begin{array}{l}\text { AAGCAG } \\
\text { AAGCAG } / \text { gtaaacttaa } \\
\text { AA2 }_{\text {gtaaacttca }}\end{array}$ & $\begin{array}{l}\text { tatcctgcag } /{ }^{143} \text { ATGTGC } \\
\text { ttcttteag/ } / 143 \text { AACCCA }\end{array}$ & $\begin{array}{r}267 \mathrm{bp} \\
1772 \mathrm{bp}\end{array}$ \\
\hline $\begin{array}{l}\text { Human } \\
\text { CHO }\end{array}$ & $\begin{array}{l}3 \\
3\end{array}$ & $\begin{array}{l}167 \\
158\end{array}$ & $\begin{array}{l}\text { GAAGAG } \\
\text { GAAGAG } \\
\text { GAtaagaatgt } \\
\text { (g) }\end{array}$ & $\begin{array}{l}\text { ttccttgaag } /{ }^{310} \text { GAAGAA } \\
\text { ttccttaaag } /{ }^{301} \text { GGGGAG }\end{array}$ & $\begin{array}{r}89 \mathrm{bp} \\
175 \mathrm{bp}\end{array}$ \\
\hline $\begin{array}{l}\text { Humen } \\
\text { CHO }\end{array}$ & $\begin{array}{l}4 \\
4\end{array}$ & $\begin{array}{l}586 \\
534\end{array}$ & & & \\
\hline
\end{tabular}

a CHO, Chinese hamster ovary.

b Adjacent exon (upper-case letters) and intron (lower-case letters) sequences are given for each junction. Also shown are nt positions (superscript numbers) of exon/intron boundaries in the GADD153 cDNA sequences.

c The first intron has not been sequenced entirely, so its size is approximate. 


\section{(b) Isolation and characterization of the human GADD153 gene}

A human lung fibroblast genomic DNA library constructed in bacteriophage $\lambda$ Fix was screened for $G A D D 153$ genomic sequences. Fifteer positive phage clones were detected in the initial screen of $10^{6}$ plaques. Two isolates were found to contain the entire gene and one of these, $\lambda b 4-1$, was used for further mapping and sequencing. As shown in Fig. 2, GADDI53 spans $3 \mathrm{~kb}$ and is divided into four exons. The overall gene structure is highly conserved from hamster to human, with exon/intron splice junctions conserved in identical positions between the two species (Table I; Fig. 1). All three introns of the human gene are smaller than those of the hamster gene accounting for the overall smaller size of the human gene. Southern-blot analysis of human genomic DNA restricted with SacI and probed with the human cDNA yielded the expected size human GADD153 fragments: $9.9,2$, and $0.2 \mathrm{~kb}$ (data not shown), and in five separate digests with enzymes which do not cut within the gene itself, only a single hybridizing band was seen. These results confirm the predicted genomic structure based on mapping analysis and suggest that the GADD153 gene is present as a single copy in the genome.

\section{(c) Chromosomal localization}

GADD153 was localized to chromosome 12 by analyzing human-rodent somatic cell hybrids (Table II). The GADD153 gene was detected as a $26-\mathrm{kb}$ band in EcoRI-digests of human DNA, and it was well resolved from a cross-hybridizing sequence in rodent DNAs. The

TABLE II

Segregation of GADDI53 cDNA with human chromosome 12 in luman.rodent cell hybrius"

\begin{tabular}{|c|c|c|c|c|c|}
\hline \multirow{3}{*}{$\begin{array}{l}\text { Human } \\
\text { chromosome }\end{array}$} & \multicolumn{4}{|c|}{ Determination on the 79 somatic cell hybrids } & \multirow{3}{*}{$\begin{array}{l}\% \\
\text { Discordancy }\end{array}$} \\
\hline & \multicolumn{2}{|c|}{ Number with $G A D D I 53$ gene } & \multicolumn{2}{|c|}{ Number without $G A D D 153$ gene } & \\
\hline & $\begin{array}{l}\text { Chromosome } \\
\text { present }\end{array}$ & $\begin{array}{l}\text { Chromosome } \\
\text { absent }\end{array}$ & $\begin{array}{l}\text { Chromosonie } \\
\text { present }\end{array}$ & $\begin{array}{l}\text { Chromosome } \\
\text { absent }\end{array}$ & \\
\hline 1 & 24 & 11 & 7 & 37 & 23 \\
\hline 2 & 19 & 16 & 4 & 40 & 25 \\
\hline 3 & 21 & 14 & 6 & 38 & 25 \\
\hline 4 & 28 & 7 & 20 & 24 & 34 \\
\hline 5 & 20 & 15 & 4 & 40 & 24 \\
\hline 6 & 29 & 6 & 14 & 30 & 25 \\
\hline 7 & 19 & 16 & 13 & 31 & 37 \\
\hline 8 & 24 & 11 & 12 & 32 & 29 \\
\hline 9 & 22 & 13 & 8 & 36 & 27 \\
\hline 10 & 16 & 19 & 3 & 41 & 28 \\
\hline 11 & 22 & 13 & 5 & 39 & 23 \\
\hline 12 & 33 & 2 & 0 & 44 & 3 \\
\hline 13 & 19 & 16 & 9 & 35 & 32 \\
\hline 14 & 21 & 14 & 14 & 30 & 35 \\
\hline 15 & 24 & 11 & 17 & 27 & 35 \\
\hline 16 & 14 & 21 & 19 & 25 & 51 \\
\hline 17 & 29 & 6 & 19 & 25 & 32 \\
\hline 18 & 20 & 15 & 17 & 27 & 41 \\
\hline 19 & Iy & 16 & 7 & 37 & 29 \\
\hline 20 & 27 & 8 & 11 & 33 & 24 \\
\hline 21 & 27 & 8 & 22 & 22 & 38 \\
\hline 22 & 17 & 18 & 10 & 34 & 35 \\
\hline$x$ & 23 & 12 & 15 & 29 & 34 \\
\hline
\end{tabular}

"A somatic-cell-hybrid mapping strategy was used to localize GADD153 gene. The isolation and characterication of , 'i has been described (McBride et al., 1982). DNA samples from 79 independent human-mouse or human-hamster somatic cell hytrir, ,. ' suc.. sis were digested with EcoRI, and fragments were resolved by electrophoresis on $0.7 \%$ agurose gels. Southern blots were prepared on nyl ant alise The contitions of Southern hybridization and washing $\left(26 \mathrm{mM} \mathrm{Na}{ }^{+}\right.$at $55^{\circ} \mathrm{C}$ ) have been deseribed (Olson et al. 1990) and allow about $10 \%$,ucuce divergence. Detection of the human sequence is correlated with the presence or absence of each human chromosome in the group of somatic cell hybrids.

${ }^{b}$ Discordance represents the presence of the gene in the absence of the chromosome or absence of the gene despite the presence of the chromosome, the sum of these numbers divided by total hybrids examined $(\times 100)$ represents \% discordancy. The human-hamster hybrids were composed of 27 primary clones and twelve subciones (17 positive of 39 total). The human-mouse hybrids contained 13 primary clones and 27 subclones (18 positive of 40 total). The discordance for chromosome $12(3 \%$; bold numerals) resulted from detection of fainlly hybridizing human sequence in two human-mouse hybrids in which chromosome 12 was not observed. This probably represents the presence of chromosome 12 in a small fraction of the cells in these two hybrid cell lines. 
GADD153 gene segregated concordantly with human chromosome 12 and discordantly $(\geq 23 \%$ ) with all other human chromosomes. Chromosome 12 was not detected in two hybrids which hybridized weakly with the GADD153 probe. This probably reflects the presence of chromosome 12 in only a small fraction of the cell population in these two hybrid cell lines. The gene was further regionally localized to 12q13.1-q13.2 by competitive in situ hybridization using biotinylated genomic DNA probes (Fig. 3). After hybridization, the typical yellowish-green fluorescence signal was observed as a double dot (i.e., signal on both chromatids) on the proximal long arm of chromosome 12 (Fig. 3A). This fluorescent signal was usually found on both copies of chromosome 12 in metaphase spread (Fig. 3B). Considering the position of the gene relative to the entire length of chromosome 12 , it is located at a position $42 \%$ of the total length below 12 pter (the terminus of the short arm of the chromosomej. Specific chromosomal aberrations in this region have been associated with several different neoplasms including uterine leiomyomas, lipomas, liposarcomas, pleiomorphic adenomas, and malignant lymphomas (Mitelman et al., 1990). In addition, an amplified nt sequence from this region was found in a malignant fibrous histiocytoma (Meltzer et al., 1992). Since GADD153 is induced by growth arrest and DNA damage, it will be important to determine whether this gene might be involved in any of these tumors.

\section{(d) Sequence comparison of the human and hamster GADD153 promoter regions}

The sequence of the human promoter region is shown in Fig. 4. Comparison of this sequence with that of 785-bp of
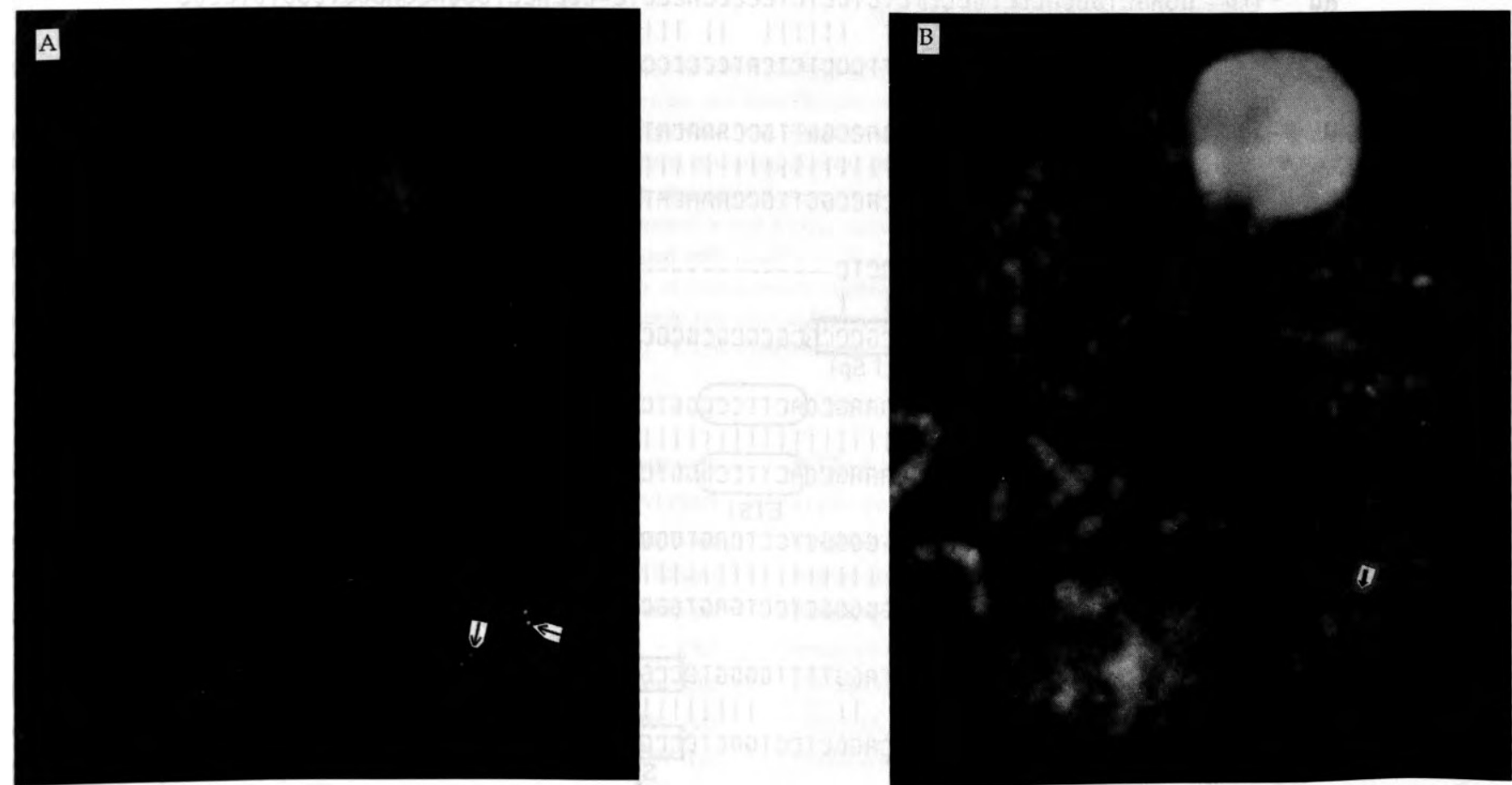

Fig. 3. In situ hybridization methods. Metaphase spreads were prepared using peripheral blood lymphocytes from a normal male (46, XY), after BrdUrd (5-bromo-deoxyuridine) synchronization (Bhatt et al., 1988) as described by Gnarra et al. (1990). Chromosomal DNA on slides was denatured for 5 min in $0.2 \mathrm{~N} \mathrm{NaOH}$ in ethanol (Landegent et al., 1985; Garson et al, 1987). Two phage $\lambda$ isolates (b4-1 and a2-1: Fig. 2C) containing the untirc GADD153 gene were labelled with biotin-14-dATP (Gibco-BRL) by nick translation and used as probe. The probe $(20 \mathrm{ng} / \mu \mathrm{l})$ and sheared HcLa DNA ( $\mu \mathrm{g} / \mu \mathrm{l})$ were dissolved in hybridization solution ( $50 \%$ formamide $/ 2 \times \mathrm{SSC} / 10 \%$ dextran sulfate) and denatured for $10 \mathrm{~min}$ at $70^{\circ} \mathrm{C}$. After reassociation of repetitive nt sequence in the probe mixture for $40 \mathrm{~min}$ at $37^{\circ} \mathrm{C}$, the complete hybridization solution was added to slides $(20 \mu \mathrm{l} / \mathrm{slide})$ and incubated for $16-20 \mathrm{~h}$ at $37^{\circ} \mathrm{C}$. Slides were washed in three changes of $50 \%$ formamide $/ 2 \times \mathrm{SSC} \mathrm{pH} 7.0\left(42^{\circ} \mathrm{C}\right)$ for $5 \mathrm{~min}$ and once in $0.1 \mathrm{M}$ phosphate buffer pH 8.0 , containing $0.1 \%$ Nonidet $\mathbf{P} 40$. The slides were then alternatively treated for 20 -min intervals at room temperature with FITC-avidin (5 $\mu \mathrm{g} / \mathrm{ml})$ and biotinylated goat anti-avidin $(5 \mu \mathrm{g} / \mathrm{ml})$ (Vector Labs) each dissolved in $0.1 \mathrm{M}$ phosphate buffer $/ 5 \%$ nonfat dry milk. Each avidin and goat anti-avidin treatment was separated by three washes ( $3 \mathrm{~min}$ each) with $0.1 \mathrm{M}$ phosphate buffer (Pinkel et al., 1988). After the second treatment with FITC-avidin, metaphase chromosomes were banded by incubation of the slides with Hoechst $33258\left(150 \mu \mathrm{g} / \mathrm{ml} \mathrm{in} \mathrm{H}_{2} \mathrm{O}\right)$ for $30 \mathrm{~min}$ at room temperature followed by illumination of spreads with long wavelength $(365 \mathrm{~nm})$ UV light for $20 \mathrm{~min}$. The slides were then reacted successively with biotinylated anti-avidin and FITCavidin prior to UV illumination again for $5 \mathrm{~min}$. A Leitz microscope with epifluorescence optics was used for photography. FITC signals were observed and photographed with a blue filter (490 nm excitation and $510 \mathrm{~nm}$ emission), and banded chromosomes were observed with a violet fiter ( $365 \mathrm{~nm}$ excitation and $460 \mathrm{~nm}$ emission). (Plate A) Typical metaphase spread with FITC-avidin fluorescence signal on both chromatids of both copies of chromosome 12. (Plate B'. luorescence-banded chromosomes of the same, metaphase spread. The arrows indicate the position of the FITC-avidin fluorescence on chromosome 12 as determined by direct observation and superimposition of the two fluorescence images (i.e., plates $\mathbf{A}$ and $\mathbf{B}$ superimposed). 


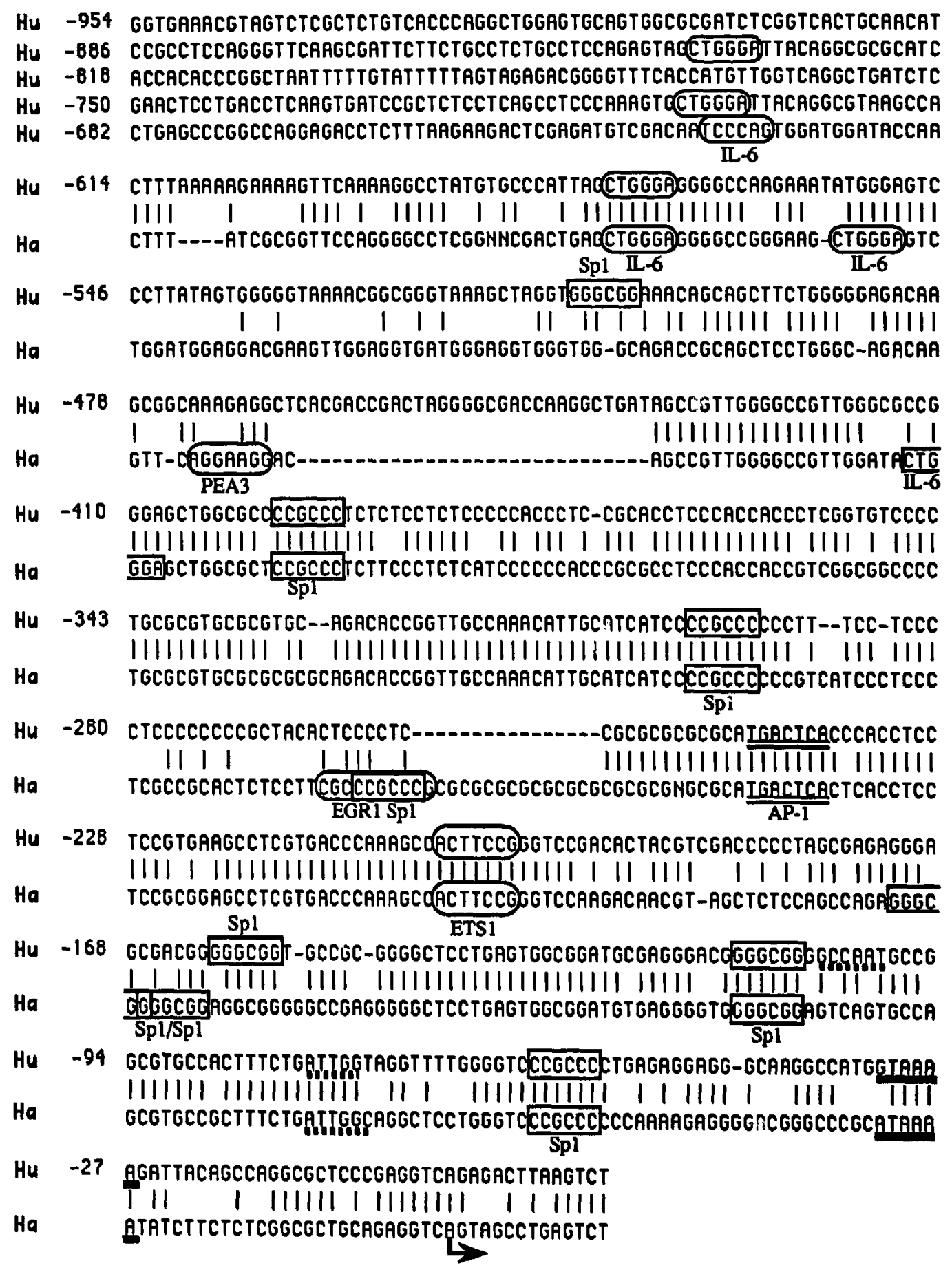

Fig. 4. Nucleotide sequence conipurison of the promoter regions of the human (upper line) and hamster (lower line) GADDI53 genes. The arrow marks the major $t s p$ in the hamster gene, of which the ' $A$ ' $n t$ is designated as +1 . A minor tsp is present 2 bp upstream at the 'T' residue. The TATA-like box is underlined with solid line; potential CAAT recognition sequences are underlined with a bold-faced dashed line. Consensus sequences for the Spl-binding sites are boxed in the solid borders; the consensus AP-1-binding site is doubly underlined. Putative ETS-1, EGR-1, PEA-3 and IL-6-responsive sites are indicated with rounded boxes.

the hamster promoter region revealed a high degree of identity within the 600-bp region proximal to the tsp. As in the hamster gene, the human flanking region is relatively $\mathrm{G}+\mathrm{C}$ rich $(70 \%$ from nt -410 to +1$)$. Both promoters contain numerous putative Spl-binding sites (5'-GGGCGG), four of which are positioned identicaliy in the two genes. TATAlike sequences are present in both genes, $32 \mathrm{bp} 5^{\prime}$ of the cap site. Although both promoters contain a $5^{\prime}-$ GCCAAT se- 


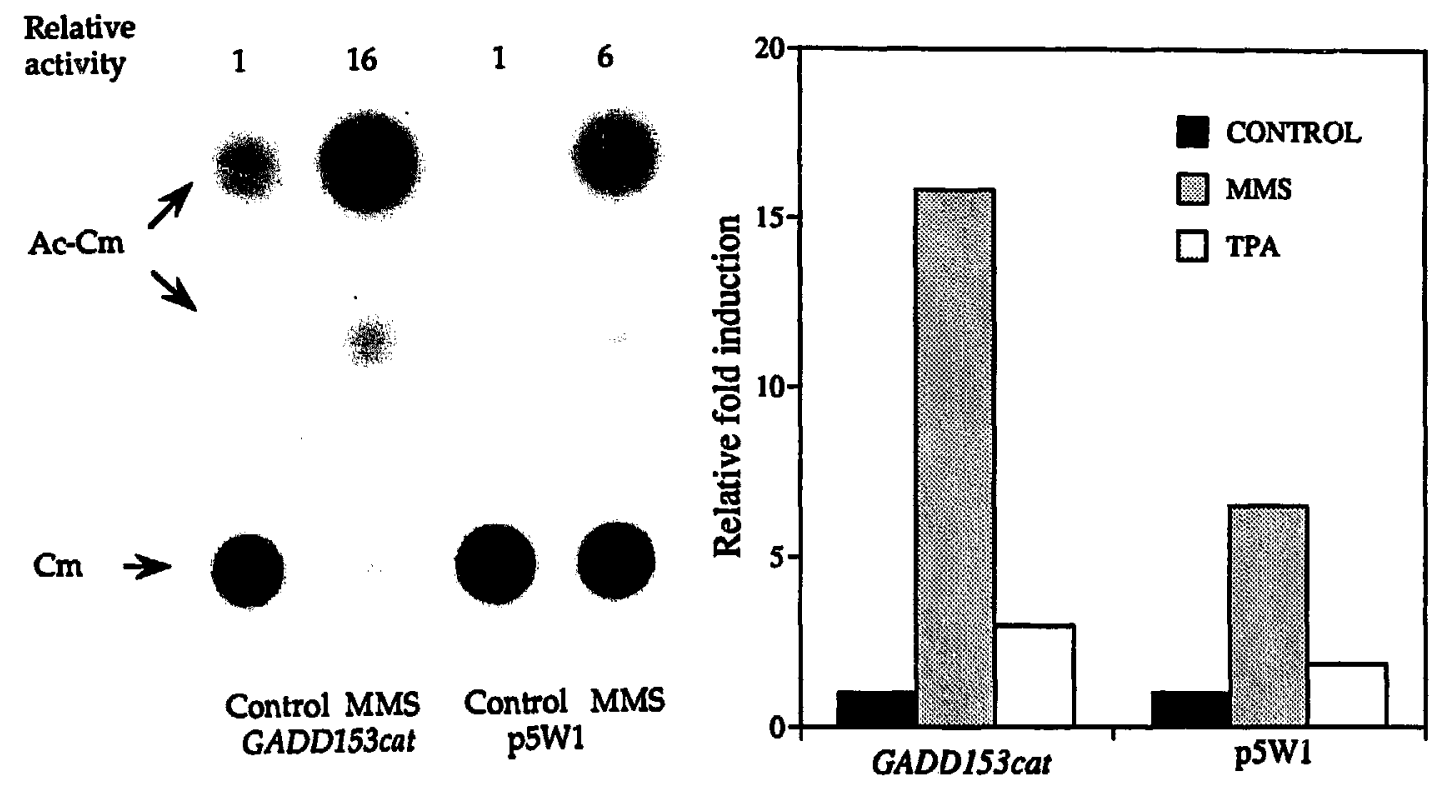

Fig. 5. Activation of the human and hamster GADD153 promoters by DNA-damaging agents. The human GADDIS3 promoter region from nt -954 to + 91 was amplified by PCR and cloned directionally between the Clal and HindIII sites of JymCATO, a promoterless and enhancerless vector construct containing the cat gene (Holbrook et al, 1987). The recombinant plasmid was designated as p5WI. GADDI53cat, which contains the hamster promoter region (nt -778 to +21$)$ linked to drive cat gene expression, has been described (Luethy et al., 1990). HeLa cells were transfected using the Ca·phosphate precipitation method and treated with MMS or TPA as previously described (Luethy et al., 1990). CAT assays were performed $24 \mathrm{~h}$ after treatment. CAT activity was determined as the $\%$ acetylation of $\left[{ }^{14} \mathrm{C}\right]$ chloramphenicol in cell lysates normalized for protein content and time of incubation. The relative fold induction is defined as the ratio of the CAT activity of treated cells relative to that of untreated cells transfected and harvested at the same time. (Left panel) A representative CAT assay. (Right panel) Summary of four separate experiments examining the effect of MMS (100 $\mu \mathrm{g} / \mathrm{ml}, 4 \mathrm{~h}$ ) and TPA $(30 \mathrm{ng} / \mathrm{ml}, 24 \mathrm{~h})$ on $\mathrm{p} 5 \mathrm{Wl}$ and GADDI53cat expression in transiently transfected HeLa cells. Values are the means of induction observed in the individual experiments. $\mathrm{Cm},\left[{ }^{14} \mathrm{C}\right]$ chloramphenicol; Ac-Cm, acetylated $\left[{ }^{14} \mathrm{C}\right]$ chloramphenicol.

quence, they are positioned differently in the human (nt -104 to -99 ) and the hamster (nt -76 to -80 ; inverted sequence) genes. However, a CAAT sequence is present in an identical position (nt -77 to -80$)$. Of particular interest is a stretch of $n t$ with high identity $(>95 \%)$ between $n t$ -256 and -190 in the human gene and $n t-258$ and -192 in the hamster gene. This 66-bp region encompasses the AP-1-binding site and a putative ETS-1 binding site. An AP-1-binding site has been shown to be responsible for the activation of both the collagenase and c-jun genes following UV radiation (Stein et al., 1989; Devary et al., 1991). In preliminary studies, we have shown that the AP-1binding site in the GADD153 promoter does bind to members of the AP-1 family of proteins, and that this AP-1binding activity is increased with DNA damage (J.F. and N.J.H., unpublished results). Thus, it is likely that the AP1-binding site does, in fact, play a role in the activation of $G A D D 153$ expression following DNA damage. However, deletion of the AP-1-binding site does not abolish the responsiveness to DNA damage, indicating that other sites are involved in the response (unpublished results). The sequence 5'-ACTTCCG has been shown to be the recognition site for the binding of the ETS-1 transcriptional activation protein (Wasylyk et al., 1989; 1991). Although
ETS-1 is lymplooid-tissue-specific, other related proteins, such as ETS-2 or the recently described NRF-2, which are broadly expressed in tissues, are also capable of interacting at this site (Virbasius and Scarpulla, 1991). ETS DNAbinding domains are present in several other DNA-damageinducible genes including human collagenase, stromelysin (Wasylyk et al., 1991) and the mouse Moloney sarcoma virus (Gunther et al., 1990), but no link to DNA damage responsiveness has yet been established. Finally, the human promoter region contains four copies of the sequence 5' CTGGGA identified in other genes as an IL-6-response element (Hattori et al., 1990). The hamster gene also contains multiple copies of this sequence.

\section{(e) Effects of DNA damage and TPA on human GADD153 promoter activity}

To examine whether the 5 -flanking sequences in the human GADD153 gene exhibit promoter activity, we constructed a chimeric gene, $\mathrm{p} 5 \mathrm{~W} 1$, containing the 5 -flanking sequences from $\mathrm{nt}-954$ to +91 relative to the $t s p$ fused to the cat reporter gene. CAT activity was measured to determine the ability of the human GADD153 promoter to drive cat expression in transiently transfected HeLa cells. For comparison, the hamster GADD153 promoter-cat con- 
struct (nt -778 to +21 ), GADD153cat, was simultaneously transfected into HeLa cells. As shown for a typical CAT assay (Fig. 5, left), the human GADD153 promoter exhibited a lower basal level (approx. fivefold less) than that observed for the hamster promoter. However, expression of $\mathrm{p} 5 \mathrm{~W} 1$ was still more than tenfold greater than that of the promoterless vector, JymCATO (not shown). Treatment of transiently transfected cells with the DNA damaging agent, MMS, a known inducer of GADD153 mRNA in human cells, resulted in a sixfold increase in human promoter activity and a 16-fold increase in hamster promoter activity. Despite the presence of the conserved AP-1-binding site in the proximal promoter region, the CAT activities from both promoters were enhanced only twofold following TPA treatment (Fig. 5, rigitt).

The lower activity of the human GADD153 promoter could reflect the presence of additional positive regulatory elements in the hamster promoter which are lacking in the human promoter. For instance, the hamster promoter contains a putative binding site for the EGR-1 protein which is absent in the human promoter, and EGR-1 mRNA expression has been shown to be induced by DNA damage (Hallahan et al., 1991). The hamster gene also contains a polyoma virus enhancer motif, PEA3 (nt -468 to -474 ), which is not present in the human gene. Alternatively, the human promoter fragment could contain negative regulatory elements which suppress its expression during normal growth and in response to DNA damaging agents. Obviously, the importance of the various cis-elements within the GADD153 gene promoter must be individually dissected. The sequence comparisons of the human and hamster promoter regions have provided important information for further studies targeting regions most likely to play a critical role in regulating $G A D D 153$ transcription.

\section{(f) Conclusions}

(1) We have isolated, sequenced, and characterized the human GADD153 gene.

(2) Comparison of the human and hamster GADD153 genes showed a high conservation in the overall gene structure with intron/exon junctions maintained at identical positions. The $n t$ sequences of the coding regions are $78 \%$ identical and aa sequences are $91 \%$ identical.

(3) Analysis of the 5 -fflanking region of the human gene revealed the presence of numerous recognition sequences for transcriptional factors. These include six Spl-binding sites, two CAAT boxes (CCAAT; GCCAAT), four IL-6 response elements, and a single recognition site each for AP-1 and ETS-1 proteins.

(4) A 900-bp fragment containing the 5 '-flanking region of $G A D D 153$ exhibited promoter activity that was enhanced by treatment with MMS.

\section{REFERENCES}

Bhatt, B., Burns, J., Flannery, D. and McGee, J.O.D.: Direct visualization of single copy genes on banded metaphase chromosomes by nonisotopic in situ hybridization. Nucleic Acids Res. 15 (1988) 39513961.

Brawerman, G.: mRNA decay: finding the right targets. Cell 57 (1989) 313-324.

Caput, D., Beutler, B., Hartog, K., Thayer, R., Brown-Shimer, S. and Cermai, A.: Identification of common nucleotide sequence in the 3 'untranslated region of mRNA molecules specifying inflammatory mediators. Proc. Natl. Acad. Sci. USA 83 (1986) 1670-1674.

Chin, D.J., Gil, G., Russell, D.W., Liscum, L., Luskey, K.L., Basu, S.K., Okayama, H., Berg, P., Goldstein, J.L. and Brown, M.S.: Nucleotide sequence of 3-hydroxy-3-methyl-glutary coenzyme A reductase, a glycoprotein of endoplasmic reticulum. Nature 308 (1984) 613-617.

Devary, Y., Gottlicb, R.A., Lau, L.F. and Karin, M.: Rapid and preferential activation of the $c-j u n$ gene during the mammalian UV response. Mol. Cell. Biol. 11 (1991) 2804-2811.

Fornace Jr., A.J., Nebert, D.W., Hollander, M.C., Luethy, J.D., Papathanasiou, M., Fargnoli, J. and Holbrook, N.J.: Mammalian genes coordinately regulated by growth arrest signals and DNA-damaging agents. Mol. Cell. Biol. 9 (1989) 4196-4203.

Garson, J.A., Van den Berghe, J.A. and Kemshead, J.T.: Novel nonisotopic in situ hybridization technique detects small ( $1 \mathrm{~kb})$ unique sequences in routinely G-banded human chromosomes: fine mapping of N-myc and $\beta$-NGF genes. Nucleic Acids Res. 15 (1987) 47614770.

Gnarra, J.R., Otani, H., Wang, M.G., McBride, O.W., Sharon, M. and Lconard, W.J.: Human interleukin 2 receptor $\beta$-chain gene: chromosomal localization and identification of $5^{\prime}$ regulatory sequences. Proc. Natl. Acad. Sci. USA 87 (1990) 3440-3444.

Gunther, C.V., Nye, J.A., Bryner, R.S. and Graves, B.J.: Sequencespecific DNA binding of the proto-oncoprotein ets-I defines a transcriptional activator sequence within the long terminal repeat of the Moloncy murine sarcoma virus. Genes Develop. 4 (1990) 667679.

Hallahan, D.E., Sukhatme, V.P., Sherman, M.L., Virudachalam, S., Kufe, D. and Weichselbaum, R.R.: Protein kinase $C$ mediates $x$-ray inducibility of nuclear signal transducers EGRI and JUN. Proc. Natl. Acad. Sci. USA 88 (1991) 2156-2160.

Hattori, M., Abraham, L.J., Northemann, W. and Fey, G.H.: Acutephase reaction induces a specific complex between hepatic nuclear proteins and the interleukin 6 response element of the rat $x_{2}$ macroglobulin gene. Proc. Natl. Acad. Sci. USA 87 (1990) 23642368.

Holbrook, N.J. and Fornace Jr., A.J.: Response to adversity: molecular control of gene activation following genotoxic stress. New Biol. 3 (1991) 825-833.

Holbrook, N.J., Gulino, A., Durand, D., Lin, Y. and Crabtree, G.R.: Transcriptional activity of the gibbon ape leukemia virus in the interleukin 2 gene of MLA 144 cells. Virology 159 (1987) 178-182.

Landegent, J.E., Jansen in de Wal, N., Van Ommen, G.-J.B., Baas, F., De Vijlder, J.J.M., Van Duijn, P. and Van der Ploeg, M.: Chromosomal localization of a unique gene by non-autoradiographic in situ hybridization. Nature 317 (1985) 175-177.

Lucthy, J.D. and Holbrook, N.J.: Activation of the gadd153 promoter by genotoxic agents: a rapid and specific response to DNA damage. Cancer Res. 52 (1992) 5-10.

Luethy, J.D., Fargnoli, J., Park, J.S., Fornace Jr., A.J. and Holbrook, N.J.: Isolation and characterization of the hamster gadd 153 gene. J. Biol. Chem. 265 (1990) 16521-16526.

McBride, O.W., Hieter, P.A., Hollis, G.F., Swan, D., Otey, M.C. and 
Leder, P.: Chromosomal location of human kappa and lambda immunoglobulin light chain constant region genes. J. Exp. Med. 155 (1982) 1480-1490.

Meltzer, P.S., Jankowski, S.A., Dal Cin, P., Sandberg, A.A., Paz, I.B., Coccia, M.A. and Smith, S.H.: Identification and cloning of a novel amplified DNA sequence in human malignant fibrous histiocytoma derived from a region of chromosome 12 frequently rearranged in soft tumors (HGM11). Cytogenet. Cell Genet. (1992) in press.

Mitelman, F., Kando, Y. and Trent, J.M.: Reprort of the committee on chromosome changes in neoplasia (in HGM 10.5). Cytogenet. Cell Genet. 55 (1990) 358-386.

Olson, S., Song, B.J., Huh, T.-L., Chi, Y.T., Veech, R.L. and McBride, O.W.: Three genes for enzymes of the pyruvate dehydrogenase complex map to human chromosomes, 3, 7, and X. Am. J. Hum. Genet. 46 (1990) 340-349.

Pinkel, D., Landegent, J., Collins, C., Fuscoe, J., Segraves, R., Lucas, J. and Gray, J.: Fluorescence in situ hybridization with human chromosome-specific libraries: detection of trisomy 21 and translo- cations of chromosome 4. Proc. Natl. Acad. Sci. USA 85 (1988) 9138-9142.

Stein, B., Rahmsdorf, H.J., Steffen, A., Litfin, M. and Herrlich, P.: UVinduced DNA damage is an intermediate step in UV-induced expression of human immunodeficiency virus type 1 , collagenase, c-fos, and metallothionein. Mol. Cell. Biol. 9 (1989) 5169-5181.

Virbasius, J.V. and Scarpulla, R.C.: Transcriptional activation through ETS domain binding sites in the cytochrome $c$ oxidase subunit IV gene. Mol. Cell. Biol. 11 (1991) 5631-5638.

Walker, G.C.: Inducible DNA repair systems. Annu. Rev. Biochem. 54 (1985) 425-457.

Wasylyk, C., Flores, P. Fiutman, A. and Wasylyk, B.: PEA3 is a nuclear target for transcription activation by non-nuclear oncogenes. EMBO J. 8 (1989) 3371-3378.

Wasylyk, C., Gutman, A., Nicolson, R. and Wasylyk, B.: The c-Ets oncoprotein activates the stromelysin promoter through the same elcments as several non-nuclear oncoproteins. EMBO J. 10 (1991) 1127-1134. 